\title{
Dampak Pembelajaran Jarak Jauh terhadap Tingkat Stres dan Kecemasan Mahasiswa selama Pandemi COVID-19
}

\author{
Rifa Fauziyyah*, Rinka Citra Awinda, Besral \\ Fakultas Kesehatan Masyarakat Universitas Indonesia \\ *Korespondensi: Rifa Fauziyyah - rifa.fauziyyah@ui.ac.id
}

\begin{abstract}
Abstrak
WHO telah menyatakan bahwa COVID-19 sebagai pandemi global, untuk mencegah penyebarannya maka kegiatan akademis di Indonesia dialihkan menjadi metode pembelajaran jarak jauh. Perubahan ini mengakibatkan mahasiswa harus beradaptasi dengan metode baru dan salah satu dampak dari hal tersebut adalah munculnya masalah kesehatan mental seperti stres dan kecemasan pada mahasiswa. Penelitian ini bertujuan untuk menunjukkan adanya peningkatan stres dan kecemasan pada mahasiswa sebagai dampak pembelajaran jarak jauh selama masa pandemi COVID-19. Metode yang digunakan adalah kajian pustaka dari jurnal nasional dan internasional yang meneliti tentang pengaruh pandemi COVID-19 terhadap stres dan kecemasan yang dialami mahasiswa. Penelusuran jurnal ini menggunakan database Google Scholar, ResearchGate, dan Pubmed. Dari 10 jurnal menunjukkan peningkatan stres dan kecemasan yang dialami mahasiswa selama pandemi COVID-19 yang disebabkan oleh berbagai faktor. Angka stres pada mahasiswa di Indonesia selama perkuliahan jarak jauh rata-rata sebesar 55,1\%, sedangkan pada mahasiswa di luar Indonesia sebesar 66,3\%. Angka kecemasan mahasiswa di Indonesia selama perkuliahan jarak jauh rata-rata sebesar $40 \%$, sedangkan pada mahasiswa di luar Indonesia sebesar $57,2 \%$. Sebagai saran, beberapa upaya dapat dilakukan seperti olahraga atau aktivitas fisik, istirahat yang cukup, melakukan hobi, sosialisasi secara virtual serta menerapkan lingkungan yang sehat baik secara fisik maupun psikologis untuk mengurangi stres dan kecemasan.
\end{abstract}

Kata Kunci: stress, kecemasan, mahasiswa, pembelajaran jarak jauh, COVID-19

\section{Impact of Distance Learning on Student Stress and Anxiety Levels during The COVID-19 Pandemic}

\begin{abstract}
WHO has declared that COVID-19 is a global pandemic, to prevent its spread, academic activities in Indonesia have been shifted to a distance learning method. This change results in students having to adapt to new methods and one of the impacts of this is the emergence of mental health problems such as stress and anxiety in students. This study aims to show an increase in stress and anxiety in students as a result of distance learning during the COVID-19 pandemic. The method used is a literature review from national and international journals that examine the effects of the COVID-19 pandemic on stress and anxiety experienced by students. This journal search used the Google Scholar, ResearchGate, and Pubmed databases. From 10 journals, it shows the increase in stress and anxiety experienced by students during the COVID-19 pandemic which is caused by various factors. The stress rate for students in Indonesia during their distance lectures is an average of 55.1\%, while for students outside Indonesia it is $66.3 \%$. The rate of anxiety among students in Indonesia during distance lectures is on average 40\%, while for students outside Indonesia it is 57.2\%. As a suggestion, some efforts can be made such as sports or physical activity, adequate rest, doing hobbies, virtual socialization and implementing a healthy environment both physically and psychologically to reduce stress and anxiety.
\end{abstract}

Key Words: stress, anxiety, students, distance learning, COVID-19 
PENDAHULUAN

WHO telah menyatakan bahwa COVID-19 atau SARS-CoV-2 sebagai pandemi global terhitung sejak Maret 2020 (1). Mengikuti kebijakan physical distancing untuk mencegah penyebaran COVID-19 yang diterapkan di Indonesia, kegiatan akademis pun dialihkan dari metode tatap muka ke metode daring. Menteri Pendidikan dan Kebudayaan mengeluarkan Surat Edaran Mendikbud Nomor 36962/MPK.A/HK/2020 yang menyatakan bahwa pembelajaran secara daring dari rumah bagi mahasiswa (2).

Perubahan ini mengakibatkan mahasiswa harus beradaptasi terhadap sistem baru yang memiliki beberapa tantangan dalam pelaksanaannya. Diantaranya yaitu, jaringan internet dan jumlah kuota internet yang dimiliki diharuskan stabil dan cukup, penyampaian materi perkuliahan tidak sejelas perkuliahan tatap muka, serta jadwal akademik yang mundur atau tertunda. Selain masalah yang berhubungan langsung dengan proses perkuliahan, terdapat juga stresor dari kehidupan sehari-hari mahasiswa itu sendiri. Dampak dari perubahan-perubahan yang dialami oleh mahasiswa selama pandemi COVID-19 berisiko mengakibatkan munculnya masalah kesehatan mental.
Masalah kesehatan mental yang meningkat di masa pandemi ini adalah stres, kecemasan, bahkan depresi. Bagi mahasiswa, pandemi ini mengakibatkan stres dan kecemasan yang berkaitan dengan perubahan proses perkuliahan dan kehidupan sehari-hari. Perhimpunan Dokter Spesialis Kedokteran Jiwa Indonesia (PDSKJI) melakukan survei mengenai kesehatan mental melalui swaperiksa yang dilakukan secara daring melalui website PDSKJI yaitu http://pdskji.org/home. Hasil swaperiksa yang dilakukan oleh 4.010 responden $(71 \%$ perempuan dan $29 \%$ lakilaki) selama lima bulan (April-Agustus 2020) menunjukkan sebanyak $64,8 \%$ responden mengalami masalah psikologis dengan proporsi $64,8 \%$ mengalami cemas, $61,5 \%$ mengalami depresi, dan $74,8 \%$ mengalami trauma. Masalah psikologis terbanyak ditemukan pada kelompok usia 17-29 tahun dan diatas 60 tahun $(3,4)$.

Swaperiksa lain dilakukan terhadap 1.552 responden berkaitan dengan tiga masalah psikologis yaitu cemas, depresi, dan trauma. Responden paling banyak adalah perempuan $(76,1 \%)$ dengan usia minimal 14 tahun dan maksimal 71 tahun. Sebanyak $64,3 \%$ responden mengalami gangguan psikologis dengan proporsi $63 \%$ mengalami cemas dan $66 \%$ mengalami depresi $(3,4)$. 
Berdasarkan data usia yang terkena dampak kesehatan mental, mahasiswa menjadi salah satunya. Penulis melakukan penelitian ini bertujuan untuk menunjukkan adanya dampak yang ditimbulkan oleh pembelajaran jarak jauh (PJJ) terhadap tingkat stres dan kecemasan mahasiswa selama pandemi COVID-19.

\section{METODE}

Penelitian ini menggunakan metode kajian pustaka terhadap jurnal nasional dan internasional yang meneliti tentang pengaruh pandemi COVID-19 terhadap kesehatan mental mahasiswa. Penelusuran jurnal menggunakan database Google Scholar, ResearchGate, dan Pubmed dengan kata kunci "Mahasiswa Covid" dan “College Students Covid" yang dipublikasi selama tahun 2020.

Kriteria inklusi jurnal yang dikaji yaitu: 1) Jurnal dalam bahasa Indonesia atau bahasa Inggris; 2) Jurnal tersedia dalam full-text; 3) Jurnal meneliti tentang stres dan kecemasan selama pandemi COVID-19; 4) Sampel penelitian berjumlah $\geq 100$ orang dan 5) Jurnal telah terakreditasi Sinta untuk jurnal nasional dan Scopus untuk jurnal internasional. Kriteria eksklusi yaitu jurnal yang duplikat, tidak sesuai dengan topik yang dibahas, dan tidak terakreditasi.

Ditemukan 2,080 hasil dengan kata kunci bahasa Indonesia, jurnal yang tersedia full text sebanyak 2,047, jurnal dengan topik stres dan kecemasan pada mahasiswa selama PJJ di masa pandemi COVID-19 sebanyak 79, dan jurnal dengan jumlah sampel diatas 100 orang sebanyak 37. Pencarian dengan kata kunci bahasa Inggris ditemukan sebanyak 21,708 hasil, jurnal yang tersedia full text sebanyak 15,883, jurnal dengan topik stres dan kecemasan pada mahasiswa selama PJJ di masa pandemi COVID-19 sebanyak 101, dan jurnal dengan sampel diatas 100 orang sebanyak 54. Setelah seleksi lebih lanjut, peneliti memilih empat publikasi berbahasa Indonesia dan enam publikasi berbahasa Inggris yang paling sesuai untuk diteliti. Jurnal-jurnal tersebut selanjutnya akan dikaji dalam Hasil dan Pembahasan.

\section{HASIL}

Dari hasil telaah literatur didapatkan 10 jurnal dengan detail penulis, judul, jumlah sampel, instrumen penelitian dan hasil penelitian seperti pada Tabel 1 . 
Tabel 1. Hasil Temuan Literatur

\begin{tabular}{|c|c|c|c|c|c|}
\hline No & $\begin{array}{l}\text { Penulis } \\
\text { (Tahun) }\end{array}$ & Judul & $\begin{array}{l}\text { Jumlah } \\
\text { Sampel }\end{array}$ & $\begin{array}{l}\text { Instrumen } \\
\text { Penelitian }\end{array}$ & Hasil \\
\hline 1 & $\begin{array}{l}\text { Cao et al. } \\
(2020)(5)\end{array}$ & $\begin{array}{l}\text { The psychological } \\
\text { impact of the COVID- } \\
19 \text { epidemic on } \\
\text { college students in } \\
\text { China }\end{array}$ & 7.143 & $\begin{array}{c}\text { Generalized } \\
\text { Anxiety } \\
\text { Disorder Scale } \\
\text { (GAD-7) }\end{array}$ & $\begin{array}{l}\text { Sebanyak } 24,9 \% \text { mahasiswa } \\
\text { pernah mengalami kecemasan saat } \\
\text { pandemi. Proporsi mahasiswa } \\
\text { dengan kecemasan ringan, sedang, } \\
\text { dan berat masing-masing adalah } \\
21,3 \%, 2,7 \% \text {, dan 0,9\%. Stressor } \\
\text { terkait COVID-19 termasuk } \\
\text { stressor ekonomi, efek pada } \\
\text { kehidupan sehari-hari, dan } \\
\text { penundaan akademik. }\end{array}$ \\
\hline 2 & $\begin{array}{l}\text { Harahap dkk. } \\
\text { (2020) (6) }\end{array}$ & $\begin{array}{l}\text { Analisis Tingkat Stres } \\
\text { Akademik pada } \\
\text { Mahasiswa Selama } \\
\text { Pembelajaran Jarak } \\
\text { Jauh di masa Covid-19 }\end{array}$ & 300 & $\begin{array}{l}\text { Kuesioner } \\
\text { skala stres } \\
\text { akademik }\end{array}$ & $\begin{array}{l}\text { Sebanyak } 39 \text { mahasiswa }(13 \%) \\
\text { mengalami tingkat stres akademik } \\
\text { tinggi, } 225 \text { mahasiswa }(75 \%) \\
\text { mengalami stres akademik sedang, } \\
\text { dan } 36 \text { mahasiswa }(12 \%) \\
\text { mengalami stres akademik rendah. }\end{array}$ \\
\hline 3 & $\begin{array}{l}\text { Hasanah dkk. } \\
\text { (2020) (7) }\end{array}$ & $\begin{array}{l}\text { Gambaran Psikologis } \\
\text { Mahasiswa dalam } \\
\text { Proses Pembelajaran } \\
\text { Selama Pandemi } \\
\text { COVID-19 }\end{array}$ & 190 & $\begin{array}{l}\text { Depression, } \\
\text { Anxiety and } \\
\text { Stress Scale } \\
\text { (DASS-21) }\end{array}$ & $\begin{array}{l}\text { Mahasiswa yang mengalami } \\
\text { kecemasan ringan dan normal } \\
\text { masing-masing sebanyak } 79 \text { orang } \\
(41,58 \%) \text { dan kecemasan sedang } \\
\text { sebanyak } 32 \text { orang }(16,84 \%) \text {. } \\
\text { Mahasiswa yang mengalami stres } \\
\text { normal sebanyak } 167 \text { orang } \\
(87,89 \%) \text { dan stres ringan } \\
\text { sebanyak } 23 \text { orang }(12,11 \%) \text {. }\end{array}$ \\
\hline 4 & $\begin{array}{c}\text { Husky et al. } \\
(2020)(8)\end{array}$ & $\begin{array}{l}\text { Stress and anxiety } \\
\text { among university } \\
\text { students in France } \\
\text { during Covid-19 } \\
\text { mandatory } \\
\text { confinement }\end{array}$ & 291 & $\begin{array}{l}\text { Online survey } \\
\text { on anxiety, } \\
\text { alcohol use and } \\
\text { stress levels } \\
\text { during the } \\
\text { confinement } \\
\text { period }\end{array}$ & $\begin{array}{l}\text { Sebanyak } 168 \text { mahasiswa }(60,2 \%) \\
\text { mengalami peningkatan } \\
\text { kecemasan sejak awal masa } \\
\text { karantina. } 135 \text { mahasiswa }(61,6 \%) \\
\text { mengalami stres sedang hingga } \\
\text { berat mengenai hidup secara } \\
\text { keseluruhan, } 139 \text { mahasiswa } \\
\text { merasakan stres sedang hingga } \\
\text { berat mengenai kesehatan orang } \\
\text { terdekat, dan } 78 \text { mahasiswa } \\
\text { merasakan stres akibat keadaan } \\
\text { finansial. }\end{array}$ \\
\hline 5 & $\begin{array}{l}\text { Islam et al. } \\
(2020)(9)\end{array}$ & $\begin{array}{l}\text { Depression and } \\
\text { anxiety among } \\
\text { university students } \\
\text { during the COVID-19 } \\
\text { pandemic in } \\
\text { Bangladesh: A web- } \\
\text { based cross-sectional } \\
\text { survey }\end{array}$ & 476 & $\begin{array}{l}\text { Generalized } \\
\text { Anxiety } \\
\text { Disorder } \\
\text { (GAD-7) }\end{array}$ & $\begin{array}{l}\text { Sebanyak } 389 \text { mahasiswa }(87,7 \%) \\
\text { memiliki gejala kecemasan ringan } \\
\text { sampai berat. Mahasiswa usia } \\
\text { awal dua puluhan }(66,58 \%) \\
\text { menunjukkan gejala kecemasan } \\
\text { yang lebih tinggi. Kecemasan } \\
\text { lebih tinggi pada mahasiswa yang } \\
\text { tidak melakukan olahraga selama } \\
\text { pandemi (61,95\%) dan memiliki } \\
\text { pemikiran bahwa mereka } \\
\text { tertinggal secara akademis } \\
(76,6 \%) .\end{array}$ \\
\hline
\end{tabular}




\begin{tabular}{|c|c|c|c|c|c|}
\hline No & $\begin{array}{l}\text { Penulis } \\
\text { (Tahun) }\end{array}$ & Judul & $\begin{array}{l}\text { Jumlah } \\
\text { Sampel }\end{array}$ & $\begin{array}{l}\text { Instrumen } \\
\text { Penelitian }\end{array}$ & Hasil \\
\hline 6 & $\begin{array}{c}\text { NurCita \& } \\
\text { Susantiningsih } \\
(2020)(10)\end{array}$ & $\begin{array}{l}\text { Dampak Pembelajaran } \\
\text { Jarak Jauh dan } \\
\text { Physical Distancing } \\
\text { Pada Tingkat } \\
\text { Kecemasan } \\
\text { Mahasiswa Fakultas } \\
\text { Kedokteran } \\
\text { Universitas } \\
\text { Pembangunan } \\
\text { Nasional "Veteran" } \\
\text { Jakarta }\end{array}$ & 100 & $\begin{array}{c}\text { Hamilton } \\
\text { Anxiety Rating } \\
\text { Scale (HARS) } \\
\text { yang telah } \\
\text { dimodifikasi }\end{array}$ & 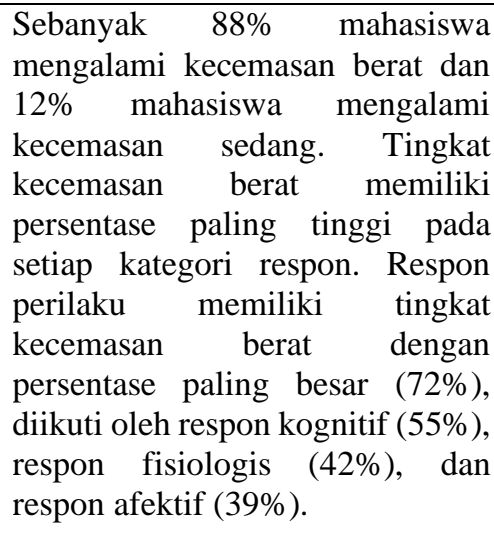 \\
\hline 7 & $\begin{array}{l}\text { Putri et al. } \\
(2020)(11)\end{array}$ & $\begin{array}{l}\text { Hubungan } \\
\text { Pembelajaran Jarak } \\
\text { Jauh dan Gangguan } \\
\text { Somatoform dengan } \\
\text { Tingkat Stres } \\
\text { Mahasiswa UIN Syarif } \\
\text { Hidayatullah Jakarta }\end{array}$ & 470 & $\begin{array}{c}\text { Depression } \\
\text { Anxiety Stress } \\
\text { Scale (DASS) }\end{array}$ & $\begin{array}{l}\text { Sebanyak } 188 \text { orang dari } 208 \\
\text { mahasiswa yang melaksanakan } \\
\text { PJJ <12 kali mengalami stres } \\
\text { tinggi. Selain itu, } 250 \text { dari } 262 \\
\text { mahasiswa yang melaksanakan } \\
\text { PJJ } \geq 12 \text { kali mengalami stres } \\
\text { tinggi. Sebanyak } 35,7 \% \\
\text { mahasiswa mengalami gangguan } \\
\text { somatoform dan } 427 \text { mahasiswa } \\
\text { menyatakan PJ tidak efektif } \\
\text { dikarenakan adanya gangguan } \\
\text { sinyal dan jaringan tidak stabil. }\end{array}$ \\
\hline 8 & $\begin{array}{l}\text { Son et al. } \\
(2020)(12)\end{array}$ & $\begin{array}{l}\text { Effect of COVID-19 } \\
\text { on College Students } \\
\text { Mental Health in the } \\
\text { United States: } \\
\text { Interview Survey } \\
\text { Study }\end{array}$ & 195 & $\begin{array}{c}\text { Perceived } \\
\text { Stress Scale-10 } \\
\text { (PSS) }\end{array}$ & $\begin{array}{l}\text { Sebanyak } 138 \text { mahasiswa }(71 \%) \\
\text { menyatakan stres dan kecemasan } \\
\text { meningkat akibat COVID-19, } 39 \\
(20 \%) \text { menyatakan tetap sama, } \\
\text { dan } 18(9 \%) \text { menyatakan stres dan } \\
\text { kecemasannya menurun. } \\
\text { Sebanyak } 54 \% \text { mahasiswa } \\
\text { menunjukkan dampak negatif } \\
\text { (ringan, sedang, berat) pada hasil } \\
\text { terkait akademik, kesehatan, dan } \\
\text { gaya hidup. Sebeesar } 89 \% \\
\text { menunjukkan kesulitan } \\
\text { berkonsentrasi saat melakukan } \\
\text { pekerjaan akademis. Mayoritas } \\
\text { mahasiswa (82\%) menunjukkan } \\
\text { kekhawatiran tentang kinerja } \\
\text { akademis akibat pandemi. } \\
\text { Tantangan terbesar yang dirasakan } \\
\text { adalah transisi ke kelas online. }\end{array}$ \\
\hline 9 & $\begin{array}{c}\text { Wang and } \\
\text { Zhao (2020) } \\
\text { (13) }\end{array}$ & $\begin{array}{l}\text { The Impact of } \\
\text { COVID-19 on Anxiety } \\
\text { in Chinese University } \\
\text { Students }\end{array}$ & 3.611 & $\begin{array}{l}\text { The Self- } \\
\text { Rating } \\
\text { Anxiety } \\
\text { Scale-SAS }\end{array}$ & $\begin{array}{l}\text { Rata-rata skor SAS lebih tinggi } \\
\text { dari normal. Mayoritas mahasiswa } \\
(66,99 \%) \text { menghadapi tingkat } \\
\text { tantangan yang berbeda dan } \\
\text { merasa sulit untuk duduk diam } \\
\text { dalam waktu yang lama. Sebanyak } \\
15,43 \% \text { mahasiswa teridentifikasi } \\
\text { gelisah pada tingkatan yang } \\
\text { berbeda, dan terdapat 20,33\% } \\
\text { siswa yang merasa lemas dan } \\
\text { mudah lelah. }\end{array}$ \\
\hline
\end{tabular}




\begin{tabular}{|c|c|c|c|c|c|}
\hline No & $\begin{array}{l}\text { Penulis } \\
\text { (Tahun) }\end{array}$ & Judul & $\begin{array}{l}\text { Jumlah } \\
\text { Sampel }\end{array}$ & $\begin{array}{c}\text { Instrumen } \\
\text { Penelitian }\end{array}$ & Hasil \\
\hline 10 & $\begin{array}{l}\text { Wang et al. } \\
(2020)(14)\end{array}$ & $\begin{array}{l}\text { Prevalence of anxiety } \\
\text { and depression } \\
\text { symptom, and the } \\
\text { demands for } \\
\text { psychological } \\
\text { knowledge and } \\
\text { interventions in } \\
\text { college students } \\
\text { during COVID-19 } \\
\text { epidemic: A large } \\
\text { cross-sectional study }\end{array}$ & 44.447 & $\begin{array}{l}\text { The Self- } \\
\text { Rating } \\
\text { Anxiety } \\
\text { Scale-SAS }\end{array}$ & \begin{tabular}{lrr} 
Prevalensi & kecemasan & pada \\
mahasiswa & sebesar & $7,7 \%$. \\
Sebanyak & $42 \%$ & mahasiswa \\
melaporkan & bahwa & mereka \\
membutuhkan & \multicolumn{2}{c}{ pengetahuan } \\
psikologis & dan & $11,2 \%$ \\
membutuhkan & & intervensi \\
psikologis selama periode epidemi \\
COVID-19.
\end{tabular} \\
\hline
\end{tabular}

\section{PEMBAHASAN}

Tinjauan pustaka terhadap 10 jurnal, yang terdiri dari empat jurnal nasional dan enam jurnal internasional menunjukkan bahwa terdapat peningkatan stres dan kecemasan yang dialami mahasiswa ketika menjalani perubahan metode pembelajaran selama pandemi COVID-19. Terdapat tiga kategori stres yang dialami, yaitu ringan, sedang, hingga berat. Beberapa hasil penelitian menunjukkan bahwa metode pembelajaran jarak jauh dinilai kurang efektif dan efisien karena masih memiliki beberapa hambatan dalam pelaksanaannya, seperti gangguan jaringan internet dan sinyal yang tidak stabil.

Vibrianti (2020) menyatakan bahwa beberapa perguruan tinggi di Indonesia merasa belum siap menggunakan teknologi pembelajaran dengan sistem daring atau jarak jauh. Beberapa permasalahan yang muncul berkaitan dengan sistem pembelajaran daring berupa kesiapan mahasiswa, penguasaan teknologi, waktu yang singkat, tugas yang banyak, jumlah kuota, dan kondisi sinyal internet. Kebijakan penutupan sementara lembaga pendidikan dengan berbagai fasilitas pendukungnya, dalam jangka pendek dan jangka menengah membuat banyak mahasiswa terdampak, khususnya mahasiswa yang tinggal di daerah dengan keterbatasan infrastruktur dan daya dukung lainnya yang semakin merasakan kesenjangan digital. Hal ini merupakan salah satu penyebab meningkatnya tingkat stres dan kecemasan yang dikategorikan dalam skala ringan, sedang, dan berat yang dialami mahasiswa selama pandemi COVID-19 (15).

Stressor yang dihadapi mahasiswa selain perubahan metode belajar yaitu diantaranya kekhawatiran ekonomi, kekhawatiran akan kesehatan keluarga dan diri sendiri, penundaan akademik, terbatasnya interaksi sosial, lapangan pekerjaan yang berkurang, dan faktorfaktor lain pada kehidupan pribadi mahasiswa. Hal ini sesuai dengan beberapa penelitian sebelumnya yang menyatakan 
bahwa mahasiswa dihadapkan pada sejumlah besar stressor yang termasuk tuntutan internal dan eksternal (16-19).

Stressor yang dihadapi mahasiswa diantaranya masalah ekonomi, kekhawatiran tentang masa depan yang tidak jelas, masalah dan peluang sosial, harapan akan dirinya sendiri, jarak jauh dari orang tua dan sanak saudara, serta permasalahan pribadi lain. Faktor akademik juga menyumbangkan potensi stres, misalnya karena perubahan gaya belajar dari sekolah menengah ke pendidikan tinggi, tugas-tugas perkuliahan, target pencapaian nilai, serta prestasi akademik. Tingkat stres yang meningkat di kalangan mahasiswa dapat mengakibatkan penurunan prestasi akademis dan dapat mempengaruhi kesehatan fisik dan mental mahasiswa (16-19).

Stres dan kecemasan pada masa pandemi COVID-19 ditentukan oleh beberapa faktor yang mempengaruhi kecepatan dan cara seseorang beradaptasi seperti kepribadian, usia, pengalaman, proses belajar, kondisi fisik, dan lingkungan (20). Kemampuan adaptasi seseorang juga berperan untuk mencegah timbulnya rasa stres dan cemas dan menentukan bagaimana seseorang menentukan cara untuk menangani perasaan-perasaan negatif yang muncul ketika dihadapkan dengan tantangan atau tekanan $(21,22)$.
Upaya pencegahan stres pada mahasiswa yang dapat dilakukan oleh pihak universitas yaitu dengan mengorganisasikan proses pembelajaran yang menarik dan komunikatif seperti voice note atau video mengajar, pertemuan lewat daring yang santai dan fleksibel, serta dapat menggunakan surel dan media sosial. Pihak kampus juga dapat menyediakan fasilitas kesehatan yang memadai ataupun melakukan kerja sama kelembagaan dengan fasilitas kesehatan untuk mendeteksi dan/atau menangani kasus COVID-19 ataupun suportif untuk kebutuhan kesehatan mental/psikologis civitas akademika dan mahasiswa $(21,22)$.

Adapun beberapa cara untuk menangani peningkatan stres dan kecemasan yang dialami mahasiswa selama masa pandemi ini, menurut Dewi terdapat tiga langkah utama yang bisa dilakukan. Pertama, disarankan untuk membekali diri dengan pengetahuan yang cukup tentang COVID-19. Kedua, mencari tahu tentang kondisi kesehatan diri melalui skrining mandiri. Ketiga, menentukan sikap dan langkah sesuai dengan kondisi kesehatan saat ini. Adapun salah satu cara untuk mengurangi stres yaitu dengan mulai membicarakan perasaan yang tengah dialami dengan orang terdekat atau orang yang dapat dipercaya untuk membantu $(23,24)$. 
Pat Walker Health Center (2020) juga menyebutkan bahwa cara yang dapat dilakukan untuk mengurangi gejala kecemasan akibat pandemi ini yaitu dengan melakukan perawatan diri. Perawatan diri mencakup berbagai cara untuk menjaga diri secara fisik, emosional dan mental. Beberapa jenis perawatan diri yang direkomendasikan untuk semua orang yaitu tidur yang nyenyak, melakukan aktivitas fisik, dan memenuhi kebutuhan nutrisi (25).

Berbagai upaya dapat dilakukan untuk menangani masalah ini, baik dari mahasiswa, pihak universitas, dan pemerintah. Mahasiswa dapat melakukan hal-hal yang dapat mencegah dan mengurangi stres serta kecemasan, seperti olahraga atau aktivitas fisik, istirahat cukup, melakukan hobi, tetap bersosialisasi meskipun secara virtual, dan apabila stres atau kecemasan terasa berat dan mengganggu, tidak segan untuk bercerita ke orang yang dipercaya atau mencari pertolongan profesional.

Saran yang dapat diberikan kepada keluarga mahasiswa yaitu untuk dapat menerapkan lingkungan rumah yang sehat, baik secara fisik maupun psikologis, untuk mengurangi stressor bagi anggota keluarga. Pihak universitas juga bertanggung jawab atas kesehatan mental mahasiswanya, sehingga dapat berkontribusi dengan memperhatikan kondisi kesehatan mental mahasiswa dan menyediakan layanan konseling atau bantuan terkait kesehatan mental lain dari psikolog/psikiater bagi civitas universitas.

Sedangkan untuk pemerintah, disarankan juga untuk lebih fokus mengerahkan sumber daya pada masalah kesehatan mental yang cukup meningkat selama masa pandemi ini untuk mewujudkan upaya penanganan yang efektif.

\section{KESIMPULAN}

Pandemi COVID-19 beserta dampakdampak yang menyertainya telah menjadi sebuah beban yang menimbulkan stres dan kecemasan bagi mahasiswa. Angka stres pada mahasiswa di Indonesia selama perkuliahan jarak jauh rata-rata sebesar $55,1 \%$, sedangkan pada mahasiswa di luar Indonesia sebesar 66,3\%. Angka kecemasan mahasiswa di Indonesia selama perkuliahan jarak jauh rata-rata sebesar $40 \%$, sedangkan pada mahasiswa di luar Indonesia sebesar 57,2\%.

Upaya-upaya yang dapat dilakukan oleh mahasiswa untuk mengatasi stres dan cemas selama PJJ diantaranya seperti olahraga atau aktivitas fisik, istirahat cukup, melakukan hobi, tetap bersosialisasi meskipun secara virtual, dan apabila stres atau kecemasan terasa berat dan mengganggu, tidak segan untuk bercerita ke 
orang yang dipercaya atau mencari pertolongan profesional.

Saran yang dapat diberikan kepada keluarga/lingkungan tempat tinggal mahasiswa yaitu untuk menerapkan lingkungan rumah yang sehat, baik secara fisik maupun psikologis, untuk mengurangi stressor bagi anggota keluarga. Pihak universitas juga dapat berkontribusi dengan menyediakan layanan konseling atau bantuan terkait kesehatan mental lain dari psikolog/psikiater bagi civitas universitas. Sedangkan untuk pemerintah, disarankan untuk lebih fokus mengerahkan sumber daya pada masalah kesehatan mental yang cukup meningkat selama masa pandemi ini untuk mewujudkan upaya penanganan yang efektif.

\section{DAFTAR PUSTAKA}

1. World Health Organization. Listings of WHO's response to COVID-19 [Internet]. World Health Organization. 2020 [cited 2020 Oct 3]. Available from: https://www.who.int/news/item/2906-2020-covidtimeline

2. Kementerian Pendidikan dan Kebudayaan Republik Indonesia. Surat Edaran Mendikbud Nomor 36962/MPK.A/HK/2020 tentang Pembelajaran secara Daring dan Bekerja dari Rumah dalam Rangka
Pencegahan Penyebaran Corona Virus Disease (COVID-19). Kementerian Pendidikan dan Kebudayaan Republik Indonesia. Kementerian Pendidikan dan Kebudayaan Republik Indonesia; 2020 .

3. Perhimpunan Dokter Spesialis Kedokteran Jiwa Indonesia. Infografik Masalah Psikologis Terkait Pandemi COVID-19 di Indonesia [Internet]. Perhimpunan Dokter Spesialis Kedokteran Jiwa Indonesia. 2020 [cited 2020 Oct 3]. Available from: http://pdskji.org/home

4. Perhimpunan Dokter Spesialis Kedokteran Jiwa Indonesia. Infografik 5 Bulan Pandemi COVID19 di Indonesia [Internet]. Perhimpunan Dokter Spesialis Kedokteran Jiwa Indonesia. 2020 [cited 2020 Oct 3]. Available from: http://pdskji.org/home

5. Cao W, Fang Z, Hou G, Han M, Xu $\mathrm{X}$, Dong $\mathrm{J}$, et al. The psychological impact of the COVID-19 epidemic on college students in China. Psychiatry Res. 2020;287:112934.

6. Harahap ACP, Harahap DP, Harahap SR. Analisis Tingkat Stres Akademik Pada Mahasiswa Selama Pembelajaran Jarak Jauh Dimasa Covid-19. Biblio Couns J Kaji 
Konseling dan Pendidik. 2020;3(1):10-4.

7. Hasanah U, Ludiana, Immawati, PH L. Gambaran psikologis mahasiswa dalam proses pembelajaran selama pandemi COVID-19. J Keperawatan Jiwa. 2020;8(3):299-306.

8. Husky MM, Kovess-Masfety V, Swendsen JD. Stress and anxiety among university students in France during Covid-19 mandatory confinement. Compr Psychiatry. 2020;102:152191.

9. Islam MA, Barna SD, Raihan $\mathrm{H}$, Khan MNA, Hossain MT. Depression and anxiety among university students during the COVID-19 pandemic in Bangladesh: A web-based cross-sectional survey. Pakpour AH, editor. PLoS One. 2020;15(8):e0238162.

10. NurCita B, Susantiningsih $T$. Dampak pembelajaran jarak jauh dan physical distancing pada tingkat kecemasan mahasiswa Fakultas Kedokteran Universitas Pembangunan Nasional "Veteran" Jakarta. J Borneo Holist Heal. 2020;3(1):58-68.

11. Putri RM, Oktaviani AD, Utami ASF, Latif N, Addiina HA, Nisa H. Hubungan Pembelajaran Jarak Jauh dan Gangguan Somatoform dengan Tingkat Stres Mahasiswa UIN Syarif
Hidayatullah Jakarta. Perilaku dan Promosi Kesehat Indones J Heal Promot Behav. 2020;2(1):38.

12. Son C, Hegde S, Smith A, Wang X, Sasangohar F. Effects of COVID-19 on college students' mental health in the United States: Interview survey study. J Med Internet Res. 2020;22(9):e21279.

13. Wang $\mathrm{C}$, Zhao $\mathrm{H}$. The Impact of COVID-19 on Anxiety in Chinese University Students. Front Psychol. 2020;11(1168):1-8.

14. Wang ZH, Yang HL, Yang YQ, Liu D, Li ZH, Zhang XR, et al. Prevalence of anxiety and depression symptom, and the demands for psychological knowledge and interventions in college students during COVID-19 epidemic: A large cross-sectional study. J Affect Disord. 2020;275:188-93.

15. Vibriyanti D. Kesehatan mental masyarakat: mengelola kecemasan di tengah pandemi COVID-19. J Kependud Indones. 2020;69.

16. Pariat ML, Rynjah A, Joplin M, Kharjana MG. Stress Levels of College Students: Interrelationship between Stressors and Coping Strategies. IOSR J Humanit Soc Sci (IOSR-JHSS. 2014;19(8):40.

17. Kariv D, Heiman T. Task-Oriented Versus Emotion-Oriented Coping 
Strategies: The Case of College Students, College Student Journal, 2005-Mar-1. Coll Stud J. 2005;39(1):72-89.

18. Santrock JW. Adolescence: perkembangan remaja (edisi keenam). Shinto BA, Saragih S, editors. Jakarta: Erlangga; 2003.

19. Legiran, Azis MZ, Bellinawati N. Faktor Risiko Stres dan Perbedaannya pada Mahasiswa Berbagai Angkatan di Fakultas Kedokteran Universitas Muhammadiyah Palembang. J Kedokt dan Kesehat Publ Ilm Fak Kedokt Univ Sriwij. 2015;2(2):197202.

20. Ali M, Asrori M. Psikologi remaja : perkembangan peserta didik. PT. Bumi Aksara. Jakarta; 2011.

21. Kementerian Kesehatan RI. Buku Panduan Kampus Siaga Covid-19. Jakarta: Kementerian Kesehatan RI; 2020.

22. Direktorat Jenderal Pencegahan dan Pengendalian Penyakit Kementerian Kesehatan RI. Pedoman Dukungan Kesehatan Jiwa dan Psikososial pada Pandemi COVID-19. Subdit Masalah Penyalahgunaan Napza Direktorat P2MKJN, editor. Direktorat Pencegahan Dan Pengendalian Masalah Kesehatan Jiwa Dan Napza, Direktorat Jenderal
Pencegahan Dan Pengendalian Penyakit, Kementerian Kesehatan RI. Jakarta: Direktorat Pencegahan Dan Pengendalian Masalah Kesehatan Jiwa Dan Napza, Direktorat Jenderal Pencegahan Dan Pengendalian Penyakit, Kementerian Kesehatan RI; 2020.

23. Dewi KS. Buku Ajar: Kesehatan Mental. Semarang: UPT UNDIP Press Semarang; 2012.

24. Ika. Cara Atasi Stres Selama Pandemi COVID-19 [Internet]. 2020 [cited 2020 Oct 3]. Available from: https://ugm.ac.id/id/newsPdf/19150cara-atasi-stres-selama-pandemicovid-19

25. Pat Walker Health Center. COVID19 Anxiety Toolbox [Internet]. Fayetteville: University of Arkansas; 2020. Available from: https://health.uark.edu/coronavirus/c aps-covid-19-resources-anxietyworkbook.pdf 